\title{
A Maritime Demarcation Dispute on the Yellow Sea Democratic People's Republic of Korea*
}

Korean Central News Agency ${ }^{*}$

\section{A Decisive Step for Defense of Sovereignty}

A general officer-level meeting between the Korean People' s Army ("KPA") and the U.S. Forces was held in Panmunjom on September 1, 1999. This meeting addressed the matter of fixing the Military Demarcation Line ("MDL") on the Yellow Sea of Korea. The meeting was proposed by the Korea People's Army to finally confirm the position of U.S. Forces before adopting its decision as to the matter of fixing the Maritime Demarcation Line on the Yellow Sea.

At the meeting, Lieutenant General RI Chan-Bok as the Chief Delegate of KPA recalled, in his speech, the sincere efforts made by KPA for a solution to this matter after the June 15 incident. KPA put forward various specified proposals at the July 21, 1999 general officer-level meeting to discuss the matter. This was out of the sincere desire and peace-loving stand of KPA to prevent military conflicts on the Yellow Sea of Korea and to ease the tense situation prevalent in the Korean peninsula at the time.

However, throughout the meeting, the U.S. Forces took a rather negative position regarding the settlement of this matter. First, the U.S. Forces refused to discuss the matter itself. At the meetings, the U.S. Forces argued that the matter should be dealt with at the inter-Korean joint military committee since the North-South agreement ("Basic Agreement") includes an article related to maritime issues. If this logic put forth by the U.S. Forces is followed, it can be also interpreted that the matters related to the MDL and the demilitarized zone should be discussed at the committee since an article dealing with these issues is contained in the Basic Agreement. Such stand and attitude

* This paper is an amended version of newspaper article originally reported by the Korean(Chosun) Central News Agency, available at http://www.kcna.co.jp in September 1999. The article was later listed at the United Kingdom National Academic Mailing Service, named "Korean Border 2" by Brendan Whyte available at http://www.jiscmail. ac.uk . 
explicitly implies that the U.S. Forces gave up its commitment to implement the Armistice Agreement ("AA") and its duty as a signatory to the AA. Further, this would mean that the U.S. Forces denied (the ultimate goal of) the general officer-level meeting between the two Koreas. Second, the U.S Forces sought to maintain the so-called Northern Limit Line ("NLL") which has been "illegally" set deep inside the Korean territorial waters. The U.S. Forces raised the legal principle, "law of prescription" for the first time at the August 17 meeting to support the illegitimacy of NLL. This argument is a far-fetched argument and does not have any legal basis in international al law.

The Chief Delegate of the KPA argued that the brigandish insistence of the U.S. Forces on the illegality of NLL cannot be construed. If otherwise, he argued that there would be an attempt to continue military conflicts on the Yellow Sea to attain its design to dominate the sea area. Further, the Chief Delegate urged the U.S. Forces to clearly answer regarding its willingness to accept the proposal from KPA for working-level contact for fixing a MDL on the Yellow Sea. However, Major General Michael Dunn, Chief Delegate of the U.S. Forces refused to accept the offer by the North Korea suggesting a working-level contact, repeating its previous unjustifiable argument that the matter must be discussed at the "north-south dialogue" and that the NLL should be observed. The Chief Delegate of the KPA, RI Chan Bok said:

Now that the stand of the U.S. Forces side has been clearly confirmed through six rounds of general officer-level meetings held so far, we will also make our own option. The KPA side will never pardon the misbehaviour of the U.S. forces side in infringing upon our sovereignty after setting a line deep inside our territorial waters at random. The KPA will take a resolute and determined measure to defend waters under our military control according to the Armistice Agreement.

\section{Special Communiqué of KPA general staff}

On September 2, 1999, the general staff of the Korean People's Army announced a special communiqué "on the proclamation of the Military Demarcation Line on the Yellow Sea of Korea." The special communiqué indicated that: "[t]he unstable tense military situation persists on the Korean peninsula in which a war may break out any moment." The gravity of this situation has increased since the June 15 exchange of fire on the Yellow Sea.

Following the Yellow Sea naval armed conflict, KPA took the initiative to call six rounds of DPRK-U.S. general officer-level meetings. This initiative was aimed to prevent recurrence of conflicts in the waters at issue, to ease the tense situation, and to made every possible effort to this end. Especially, KPA advanced a realistic proposal to define the Military Demarcation Line on the Yellow Sea through dialogues and contacts 
between the two responsible parties, grasping the stark situation in which the military conflicts on the Yellow Sea are mainly ascribable to the different assertions of the two warring sides as to the MDL. In this regard, KPA proposed to the U.S. Forces the detailed procedures such as date and place of working-level contact, number of participants and form of the contact, and made its sincere efforts to realize it. KPA also expressed its intention to allow the participation of the South Korean representatives in the contact, in consideration of their desire to take part in the discussion of the matter, despite the fact that South Korea is not a signatory to the Armistice Agreement.

It was the position of the KPA that the U.S. Forces should respond to its proposal detailed procedures on the working-level contact should it be interested in the relaxation of the military tension on the Korean peninsula even the least. The U.S. Forces, however, shunned the discussion of the issue in contravention of the Armistice Agreement and turned down the KPA proposal on the working-level contact, leaving it to the North-South Joint Military Commission. This was reviewed to the North as a crafty work of the U.S Forces to maintain the NLL, unilaterally fixed by the U.S Forces, in the Korean territorial waters.

NLL lacks legitimacy in international law. It is a line drawn by the U.S. Forces by a unilateral act in the Korean territorial waters in defiance of the Korean Armistice Agreement and international law. The U.S. Forces insisting on keeping NLL is similar to drawing a line in other's courtyard by stealth and arguing that it is its own. Accordingly, the U.S. Forces' insistence on keeping the NLL constitutes a grave encroachment upon the sovereignty of the DPRK.

The behavior of the U.S. Forces to avoid the discussion of the matter showed that it relinquished its authority and duty under the Armistice Agreement. Under this situation that the U.S. Forces argued for the illegal NLL and attempted to avoid the discussion of the issue - despite the intention of the KPA to settle the issue of Military Demarcation Line on the Yellow Sea through negotiations - the KPA general staff solemnly declared in defense of inviolable waters under the DPRK military control as follows:

1. The Military Demarcation Line on the Yellow Sea of Korea will be an extension line of the provincial boundary line (A-B) between Hwanghae-do (province) and Kyonggi-do (province) stipulated in the Armistice Agreement. The line links the point (37 degrees 18 minutes 30 seconds N, 125 degrees 31 minutes 00 second E) equidistant from " $\mathrm{A}$ " point and Tongsan point, the tip of Kangryong peninsula under the DPRK control, and from Kul-op Island under the U.S. military control the point (37 degrees 1 minute 12 seconds N, 124 degrees 55 minutes 00 second E) equidistant from Ong Island under the DPRK control and from Sogyokryolbi Island and Sohyop Island under the U.S. military control - the point southeast of it (36 
degrees 50 minutes 45 seconds N, 124 degrees 32 minutes 30 seconds E) - and the maritime demarcation line between the DPRK and China. The waters north of the line will be waters under the KPA side's military control.

2. We declare that the brigandish the "Northern Limit Line" unilaterally defined by the U.S. forces side inside our territorial waters of the Yellow Sea is invalid.

3. Our self-defensive right to the Military Demarcation Line on the Yellow Sea will be exercised by various means and methods. 090201 - Kim Yong Sun meets delegates of South Korean organizations for reunification.

KIM Yong-Sun, chairman of the Korean Asia-Pacific Peace Committee met on September 1, 1999 and conversed with adviser RA Chang Sun, a delegate, and SO Won Chol, a youth delegate of the south headquarters of the National Alliance for the Country's Reunification (Pomminryon), RI Song U, PAK Ki Su and KANG Hyong Gu, delegates of the "National Alliance for Democracy and Reunification," and HWANG Hye Ro, delegate of the South Korean Federation of University Student Councils (Hanchongryon) which represents the south headquarters of the National Alliance of Youth and Students for the Country's Reunification (Pomchonghakryon). They had participated in the grand pan-national pro-reunification festival.

Present there were AN Kyong-Ho, director of the secretariat of the Committee for the Peaceful Reunification of DPRK and vice-chairman of the north headquarters of Pomminryon, KIM In-Ho, chairman of the north headquarters of Pomchonghakryon, and officials concerned.

\section{Defunct the "Northern Limit Line"}

The United States has lost its control over the "Northern Limit Line." It set waywardly as the Military Demarcation Line on the Yellow Sea. The general staff of the KPA announced a special communiqué on September 2, 1999, in which it declared the "Northern Limit Line" invalid and fixed the MDL on the Yellow Sea. According to the communiqué, the fixed demarcation line on the Yellow Sea runs from the point "A" of the provincial boundary line (A-B) between Hwanghae-do province and Kyonggi-do province to the maritime border line between Korea and China, passing through the point (37 degrees 18 minutes 30 seconds $\mathrm{N}, 125$ degrees 31 minutes 00 seconds $\mathrm{E}$ ) equidistant from Tungsangot, the tip of Kangryong peninsula under the DPRK control, and Kulop Island under the U.S. military control - the point (37 degrees 1 minute 12 seconds N, 124 degrees 55 minutes 00 second E) equidistant from Ong Island under the DPRK control and Sogyokryolbi and Sohyop islands under the U.S. military control - and 
the point southwest ( 36 degrees 50 minutes 45 seconds N, 124 degrees 32 minutes 30 seconds E). As the result of this declaration, the waters north of the line have come under the KPA military control.

An armed conflict took place between the KPA and the South Korean army in the waters of the Yellow Sea on June 15, 1999. The conflict between the two sides brought about an unprecedented tragedy of bloodshed that resulted in sinking of battleships and human losses. This conflict along with other military conflicts were mainly ascribable to the different assertion of the two Koreas about the maritime demarcation line. To prevent recurrence of conflicts in the waters at issue and ease the tense situation, the DPRK and the United States had six rounds of general officer-level meetings, two rounds of colonel-level meetings and several contacts between staff officers so far. At these meetings, the KPA side proposed to fix the Military Demarcation Line by extending the provincial boundary line between Hwanghae-do province and Kyonggi-do province (A-B) stipulated in Article 2, Section 13, paragraph 13, b of the Armistice Agreement. On the contrary, the U.S. Forces never changed its original position on the "Northern Limit Line."

The "Northern Limit Line" is an illegal demarcation that the U.S. Forces side unilaterally set deep inside the DPRK territorial waters, disregarding the Armistice Agreement and international law. The U.S. Forces insistence on this "line" is a grave encroachment upon the DPRK's sovereignty. Therefore, the KPA could not but take its unilateral option. In light of the illegal basis of the NLL, the DPRK is legally entitled to exercise its right to defend the waters under its military control.

\section{Legitimate Self-Defensive Measure}

On September 2, 1999, the general staff of the Korean People's Army announced the special communiqué on the proclamation of the Military Demarcation Line on the Yellow Sea of Korea. Rodong Shinmun (Labor Newspaper) declared it a legitimate selfdefensive measure to ensure peace and to ease the tense situation in the Korean peninsula and furthermore, to defend the dignity and sovereignty of DPRK.1 Stressing that the DPRK regards its dignity and sovereignty as the utmost importance factor, the Rodong Shinmun stated that the measure demonstrated once again the revolutionary will of the people of DPRK and its army not to allow any encroachment upon its dignified sovereignty and inviolable territory and waters.

The people and army of DPRK were fully supportive of this step taken to defend the legitimate territorial waters under its military control, Rodong Shinmun indicated, and it goes on as follows:

1 Rodong Shinmun (Labor Newspaper), Sept. 4, 1999. 
The Military Demarcation Line on the Yellow Sea of Korea has been defined as a clear and unquestioned one by the special communique of the KPA general staff. The U.S. Forces has no ground whatsoever to take issue with this most fair and aboveboard self-defensive measure of the DPRK as it fully conforms to the requirements of the Korean Armistice Agreement and the international law. It is all the more reasonable as the United States has refused so far to discuss the matters related to fixing the maritime demarcation line and given up its authority and duty under the Armistice Agreement of its own accord.

The article reiterates that there is no other Military Demarcation Line on the Yellow Sea than the line proclaimed by the DPRK. It further urged the South Korean rulers to stop putting forth an impudent argument on this matter. If the U.S. and the South Korean rulers continued to insist on the "Northern Limit Line" to make a challenge to the DPRK, they will entirely be blamed for all the consequences arising thence. Minju Chosun (Democratic Korea magazine) in its editorial article hailed the special communique of the KPA general staff as a decisive step for the firm defense of sovereignty. 